\title{
Distribution of occult fractures detected in emergency orthopedic patient trauma with computerized tomography
}

\author{
Acil ortopedik travma hastalarında bilgisayarlı tomografi ile tanınan \\ gizli kırıkların dağılımı
}

Ahmet İMERCİ, ${ }^{1}$ Umut CANBEK, ${ }^{2}$ Ahmet KAYA, ${ }^{3}$ Levent SÜRER, ${ }^{4}$ Ahmet SAVRAN ${ }^{3}$

\section{BACKGROUND}

Computerized tomography (CT) is a very useful diagnostic method in orthopedic emergency cases where fractures are suspected but cannot be detected through direct radiography, or when the fracture is detected in direct radiography but better evaluation of the anatomical structure is necessary. In this study, we analyzed occurrences of missed fractures in radiographs that were subsequently diagnosed in CT scans.

\section{METHODS}

This was a retrospective study. We examined the medical records of all orthopedic trauma patients who visited our hospital's emergency room due to orthopedic trauma between January 2010 and January 2011 and whose spine, pelvis and extremity CTs were taken.

\section{RESULTS}

Occult fractures were detected using CT in $12(6.6 \%)$ of the children and $102(6.8 \%)$ of the adults. We detected cervical vertebra fractures in 23 patients, femoral neck fractures in 6 patients, and tibia plato fractures in 5 patients, which can cause complications unless immediately acted upon in the emergency room.

\section{CONCLUSION}

CT revealed most missed diagnoses and proved that direct radiography is less capable of detecting fractures of some critical regions. Where there is clinical suspicion, we recommend that before conservative treatment of patients, especially in cases of possible cervical spine and pelvic region fractures, CT should be requested, even if the radiography is normal.

Key Words: Computed tomography; emergency orthopedic trauma; missed diagnosis; occult fracture; radiography.

\section{$\boldsymbol{A M A C}$}

Bilgisayarlı tomografi (BT) acil ortopedik travma hastalarında kırıktan şüphelendiğimizde, direkt grafi ile tanınamayan veya direkt grafi ile tanınan ama anatomik yapılar hakkında daha iyi değerlendirme imkanı sağlayan çok yararlı bir tanı yöntemidir. Bu çalışmada radyografi ile atlanmış sonrasında BT ile tanı almış kırıklar ile ilgili deneyimlerimizi sunduk.

\section{GEREÇ VE YÖNTEM}

Bu geriye dönük çalışmada, Ocak 2010 ile Ocak 2011 tarihleri arasında ortopedik travma nedeniyle hastanemiz acil servisine başvuran, omurga, pelvis ve ekstremite BT'si çekilen bütün ortopedik travmalı hastaların tıbbi kayıtları gözden geçirildi.

\section{BULGULAR}

Sonuç olarak erişkinde $102(\% 6,8)$ ve çocuklarda 12 hastada $(\% 6,6)$ BT kullanılarak gizli kırık saptandı. Acil serviste müdahale edilmediği takdirde komplikasyonlara neden olan ve kötü prognoza sahip servikal vertebra kırığı 23, femur boyun kırığı 6 ve tibia plato kırığı 5 hastada saptandı.

\section{SONUÇ}

Ortopedik travması olan hastalarda, atlanmış tanıların ortaya çıkarılması seyrektir. BT atlanmış tanıların çoğunu ortaya çıkarmış ve radyografinin bazı önemli bölgelerin kırıkların saptanmasında düşük bir yeteneğe sahip olduğunu ortaya koymuştur. Klinik şüphenin olduğu durumlarda, radyografi normal olsa bile, özellikle servikal omurga ve pelvik bölge travmalı hastaların konservatif tedavisinden önce BT çekilmesini öneriyoruz.

Anahtar Sözcükler: Bilgisayarlı tomografi; acil ortopedik travma; atlanmış tanılar; gizli kırık; radyografi.
${ }^{1}$ Department of Orthopedics and Traumatology, Erzurum Palandoken State Hospital, Erzurum; ${ }^{2}$ Department of Orthopedics and Traumatology, Mugla Sitk1 Kocman University Faculty of Medicine, Mugla; ${ }^{3}$ Department of Orthopedics and Traumatology, Izmir Tepecik Training and Research Hospital, Izmir; ${ }^{4}$ Department of Orthopedics and Traumatology, Erzurum Regional Training and Research Hospital, Erzurum, Turkey.

\footnotetext{
${ }^{1}$ Erzurum Palandöken Devlet Hastanesi, Ortopedi ve Travmatoloji Kliniği, Erzurum; ${ }^{2}$ Muğla Sitkı Kocman Üniversitesi Tıp Fakültesi,

Ortopedi ve Travmatoloji Kliniği, Muğla; ${ }^{3}$ İzmir Tepecik Eğitim ve Araștırma Hastanesi, Ortopedi ve Travmatoloji Kliniği, İzmir; ${ }^{4}$ Erzurum Bölge Eğitim ve Araştırma Hastanesi, Ortopedi ve Travmatoloji Kliniği, Erzurum.
} 
Direct radiography has a key role in detecting fractures and dislocation in extremity and pelvis traumas. Radiography is still one of the most frequently used examinations in emergency departments (EDs) despite many new generation imaging methods because of its accessibility, relative cheapness, and high potential to help diagnosis. Of all patients examined in EDs, 35-61\% were subjected to radiological evaluation. ${ }^{[1]}$ Optimum benefit from radiography depends on technically proper imaging and accurate evaluation. Computerized tomography $(\mathrm{CT})$ is one of the imaging methods used in EDs. ${ }^{[2]}$

CT is not only used to better understand the fracture anatomy and make a surgical plan for both adult and child patients, but also to investigate the occult pelvis, extremity, and vertebral fractures for which direct radiography revealed negative results. ${ }^{[2,3]} \mathrm{CT}$ should be considered for patients with suspected spine, knee, pelvis, and hip traumas which can cause catastrophical consequences if not detected early because direct radiography is inadequate..$^{[2,4-10]}$

Trauma surgeons need to understand the types of injuries that might be missed by direct radiography, and whether these missed diagnoses might influence the management and the prognosis of the patients. The missed diagnoses could be discovered using a CT scan or other diagnostic tools. Accordingly, we conducted a retrospective study to determine the frequency and character of missed diagnoses after radiography in orthopedic trauma patients.

\section{MATERIALS AND METHODS}

The number of patients examined in the adult and child ED of our hospital between January 1, 2010 January 1, 2011 was 183.552 and 171.450 respectively. The records for the application of CT on children (aged 0-14) and adults (aged 14+) visiting the emergency trauma section in 2010 were analyzed. During this analysis, we used emergency examination cards, computer-based hospital registration system, and pre$\mathrm{CT}$ direct radiographies and $\mathrm{CT}$ images taken from computer archive (PACS). The analyses were done by one orthopedist and one radiologist. The reasons for demanding a tomography and findings of the physical examination were recorded. Occult fractures, injuries that have no radiographic indicators that occur following trauma or without any trauma, are characterized by pain and detected by CT. Those fractures, which appear normal in direct radiography but can be detected by CT, were evaluated as occult fractures. The CTs were grouped as extremity, pelvic, cervical, thoracic, and lumbar spine. Iliac bone, sacrum, acetabulum, and hip joint CTs were classified as pelvis CT in general. All data were also classified as child (aged 0-14) and adult (aged $14+$ ). All patients in this study were ex- amined and had CTs requested by the same team of doctors.

The data were analyzed using SPSS version 15.00 pack program. Chi-square and two sided analyses were used where appropriate and the alpha value was accepted as 0.05 .

\section{RESULTS}

Out of 32.685 patients examined in child and adult emergency trauma units over one year, 1.664 were asked for an extremity, pelvis, and spine CT (7.02\%). The mean age of the patients was 38.6 (2-94).

Occult fractures were detected in 37 of the 493 extremity CTs of adults, and in 2 of the 56 extremity CTs of children. Occult fractures were detected in 14 of the 169 adult pelvis CTs and 2 of the 6 child pelvis CTs. Occult fractures were detected in 16 of the 504 adult cervical CTs and 7 of the 107 child pelvis CTs. Occult fractures were detected in 3 of the 44 adult thoracic vertebra CTs and 1 of the 4 child thoracic vertebra CTs. Occult fractures were detected in 32 of the 273 adult lumbar vertebra CTs and none of the 8 children lumber vertebra CTs (Table 1). The most frequent occult spine fractures were detected as lamina fracture in 12 cases, transverse process fractures in 8 cases, and spinosis process fractures in 7 cases (Table 2).

A total of $12(6.6 \%)$ occult fractures were detected in children, and $102(6.8 \%)$ in adults. We also observed that there was a significant difference in favor of children between two groups in detecting occult fractures $(p<0.004)$. However, significantly more occult fractures were seen in the cervical area of children $(p=0.033)$. In adults, significantly more occult fractures were seen in the lumbar area $(\mathrm{p}<0.001)$, and occult fractures were seen the least in the cervical area $(p<0.001)$. No significant difference was found in detecting the fractures in all areas in total $(\mathrm{p}=0.427)$.

\section{DISCUSSION}

An analysis of the rates of occult fracture detection as a result of the retrospective analysis of CT examinations requested by trauma units in child and adult EDs revealed that $\mathrm{CTs}$ can change treatment significantly.

Table 1. The distribution of occult fractures detected in emergency trauma patients with computerized tomography

\begin{tabular}{lccc}
\hline Occult fracture & Adults (\%) & Child (\%) & Total (\%) \\
\hline Extremity CT & $37(7.5)$ & $2(3.5)$ & 39 \\
Pelvis CT & $14(8.2)$ & $2(33.3)$ & 16 \\
Cervical CT & $16(3.1)$ & $7(6.5)$ & 23 \\
Thoracic CT & $3(6.8)$ & $1(25)$ & 4 \\
Lumbar CT & $32(11.7)$ & - & 32 \\
Total CT & $102(6.8)$ & $12(6.6)$ & $114(6.8)$ \\
\hline
\end{tabular}


Table 2. The distribution of occult fractures detected in extremity and pelvis patients with computerized tomography

\begin{tabular}{llll}
\hline Upper extremity & $\mathrm{n}$ & Lower extremity & $\mathrm{n}$ \\
\hline Scapula fracture & 2 & Sacrum fracture & 7 \\
Proximal humerus fracture & 2 & Pubic rami fracture & 1 \\
Radial head fracture & 6 & Collum femoris fracture & 6 \\
Coronoid proces fracture & 1 & Patella fracture & 4 \\
Radius distal fissure & 1 & Tibia plato fracture & 5 \\
Scaphoid fracture & 2 & Fibular head fissure & 1 \\
Capitatum fracture & 1 & Posterior malleolus fracture & 3 \\
Lunatum fracture & 1 & Tuber calcanei fracture & 6 \\
& & Fibular sesamoid fracture & 1 \\
& & Navicular fissure & 1 \\
\hline
\end{tabular}

The frequent locations of these fractures include collum femoris, spine, pelvis, scaphoid, sacrum, coccyx, sternum, tarsometatarsal region, patella, and sesamoid bone. ${ }^{[11]}$ In case the occult fractures in these bones are unclear, further examination is needed in patients whose direct radiographies are normal. ${ }^{[2,12-14]}$ In the present study the most common occult fractures observed were sacrum fractures $(n=7)$, collum femoris fractures $(n=6)$, and radius head fractures $(n=6)$.

Emergency and orthopedic doctors should apply radiographic requests based on a plan that utilizes resources wisely. ${ }^{[2]} \mathrm{CT}$ is a reliable, noninvasive, painless, easy-to-apply examination method and quite sensitive in detecting the pathologies in bone structure. It is especially important to request CTs based on true justifications and to minimize dosage while obtaining the diagnostic information using the due examination method. ${ }^{[15,16]}$

\section{Cervical}

In the ED, physical examination of the cervical spine is difficult because movement of this area in patients with possible spinal injury is prohibited, and the ability of the physician to predict such injury on the basis of history and physical examination is poor. ${ }^{[17-19]}$ Conventional radiography remains an excellent screening test when the probability of injury is high and the consequences of missing a fracture could be catastrophic. ${ }^{[20-22]}$ Conventional tomography has advantages when nondisplaced dens fractures or facet fractures are being evaluated. CT is particularly useful in assessing fractures of the occipital condyles, Jefferson fractures, atlantoaxial rotatory dislocations, burst fractures with retropulsed fragments, and injuries to the cervicothoracic junction. ${ }^{[20,23-25]}$

Acheson et al. ${ }^{[11]}$ revealed that though radiographs suggested fractures in vertebrae, most so-called occult fractures (i.e., fractures detected on CT scans but not on conventional radiographs) were located in different parts of the vertebrae, such as in the pedicle, than those found in radiographs. Fractures of the occipital condyles are difficult to diagnose because findings on plain radiographs are frequently normal. ${ }^{[20]}$ In 1996 , Nuñez et al. ${ }^{[15]}$ reported that nearly $40 \%$ of cervical spine fractures are missed on conventional radiography but are later revealed on CT. Delays in diagnoses of clinically significant cervical spine injuries have been reported in approximately $5 \%$ to $23 \%$ of patients in various series, most of which used plain radiography as the initial screening modality. Neurologic deterioration (possibly secondary to mismanagement) occurred in $10 \%$ to $50 \%$ of these patients. ${ }^{[26,27]}$ In contrast, development of a secondary neurologic deficit occurred in only $1.4 \%$ of patients whose injuries were detected on initial screening in Reid and coworkers' cohort. ${ }^{[28]}$

Generally, it has been accepted that $10-20 \%$ of all significant cervical spine injuries are missed by standard radiographs. ${ }^{[18,22]}$ Of note, all the cervical spine injuries missed by plain films required some form of treatment, and 13 of these were unstable injuries requiring surgical stabilization. ${ }^{[5]}$ A total of 23 cervical occult fractures were detected in our study. Six of the 16 occult fractures detected in adults were surgically stabilized, and 7 occult fractures detected in children were traced conservatively (Fig. 1a-c).

\section{Thoracic and lumbar spine}

The options for thoracic and lumbar spine radiographs are far less complicated than those for the cervical spine. ${ }^{[26,27]} \mathrm{AP}$ and lateral films are adequate to rule out thoracic or lumbar spine injuries in most cases. As stated previously, the upper thoracic spine can be difficult to visualize with plain films and should be included as part of a cervical CT scan if indicated. Obscuring soft-tissue shadows in obese patients can make interpretation of plain radiographs difficult; this may prompt CT evaluation for spinal clearance. A CT also should be obtained in those patients with continued pain and tenderness or a neurologic deficit despite negative plain radiographs. ${ }^{[21,29]}$ In most cases, 

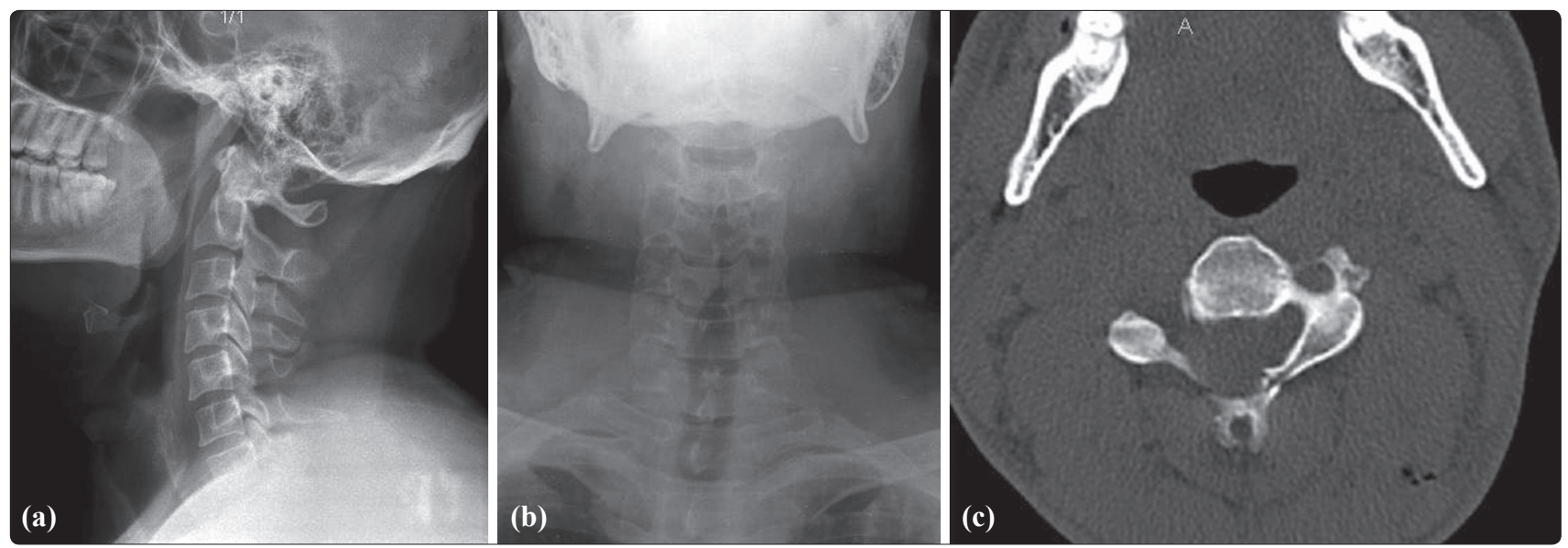

Fig. 1. (a) The normal appearance of the lateral cervical radiography. (b) The normal appearance of the AP cervical radiography. (c) Lamina fracture of third cervical vertebra in axial CT.

a CT is obtained to evaluate an injury identified by plain radiographs. Incidental injuries, such as spinous process and transverse process fractures, often are coincidentally detected on chest or abdominal CT scans obtained for non-spine reasons. ${ }^{[21,26]}$

\section{Sacrum}

Dedicated sacral images are usually not a routine component of the spine evaluation and in fact lie more within the auspices of pelvic fracture evaluation. However, dedicated pelvic views should be obtained in patients with fractures or dislocations of the lumbosacral junction. This includes an AP pelvis (which is usually obtained as part of the initial trauma series) and pelvic inlet and outlet views. Pelvic ring fractures that include the sacrum are routinely evaluated by CT. ${ }^{[21,30]}$ In our study occult sacrum fractures were detected in 7 patients, and 2 patients had neurological deficiency. If the sacrum fracture is not immobilized, it causes or deteriorates the neurological damage. While this is a medicolegal threat for the doctor who relies solely on direct radiography, it means destruction for the patient. As neurological damage can develop in sacral area fractures, routine pelvis CT is quite useful in early diagnosis.

\section{Extremity and pelvis}

Occult scaphoid fracture: If no fracture is visible on radiographs six weeks after trauma, it is considered safe to discontinue immobilization. This strategy, however, includes weeks-long unnecessary immobilization in some patients, which results in both a reduction in the quality of life and an increase in health care costs. ${ }^{[31]}$ In cases of negative or equivocal findings, additional projections (i.e., scaphoid views and/ or magnification views) have been reported to increase sensitivity. ${ }^{[31,32]}$ However, immediately after injury, up to $65 \%$ of scaphoid fractures remain radiographically occult. ${ }^{[32]}$ In our study occult scaphoid fractures were detected in two patients, and such patients should be subjected to CT alternatively as most scaphoid fractures are missed in direct radiographies.

Occult hip and pelvic fracture: The challenge for emergency physicians is to diagnose this subset of patients at the point of care, because significant morbidity can result when a patient ambulates on an unrecognized hip fracture. ${ }^{[8]}$ Surprisingly, there are limited data as to the overall incidence of hip fracture that is not radiographically apparent on plain radiographs, particularly with respect to patients presenting to the ED with hip injury. ${ }^{[8,10,33]}$ Of the pelvic and hip fractures, $8 \%$ were not identified by plain radiograph as compared with $6.8 \%$ in their population. ${ }^{[10]}$ Dominguez et al. ${ }^{[10]}$ found that the most common fractures identified by magnetic resonance imaging after negative plain radiographs included the pubic rami $(34.5 \%)$, the sacrum $(27.6 \%)$, the femoral neck $(13.8 \%)$, and the intertrochanteric region $(6.9 \%)$. We found that $4.4 \%$ of the ED patients with hip pain who had negative plain radiographs were subsequently diagnosed as having fractures. ${ }^{[33]}$ Further studies are warranted to identify characteristics of patients requiring advanced hip imaging studies. Immediate in situ nailing was used in six patients with detected femoral neck fracture (Fig. $2 a, b)$. Occult posterior pelvic ring fractures are easily missed in geriatric patients with pubic rami fractures following a simple fall. ${ }^{[8]}$ Occult pubic rami fracture was detected in one of our patients.

In our study occult plateau fractures were detected in five patients. Three of them were schatzker type 1; two were type 2 (Fig. 3a-c). If these fractures, which are treated conservatively, cannot be detected early and the patient applies load early, the collapse in the joint accelerates and requires surgical treatment. In a similar vein, the early diagnosis of the patellar fractures and immobilization of the knee in the early phase is important. During the flexion of the immobilized 

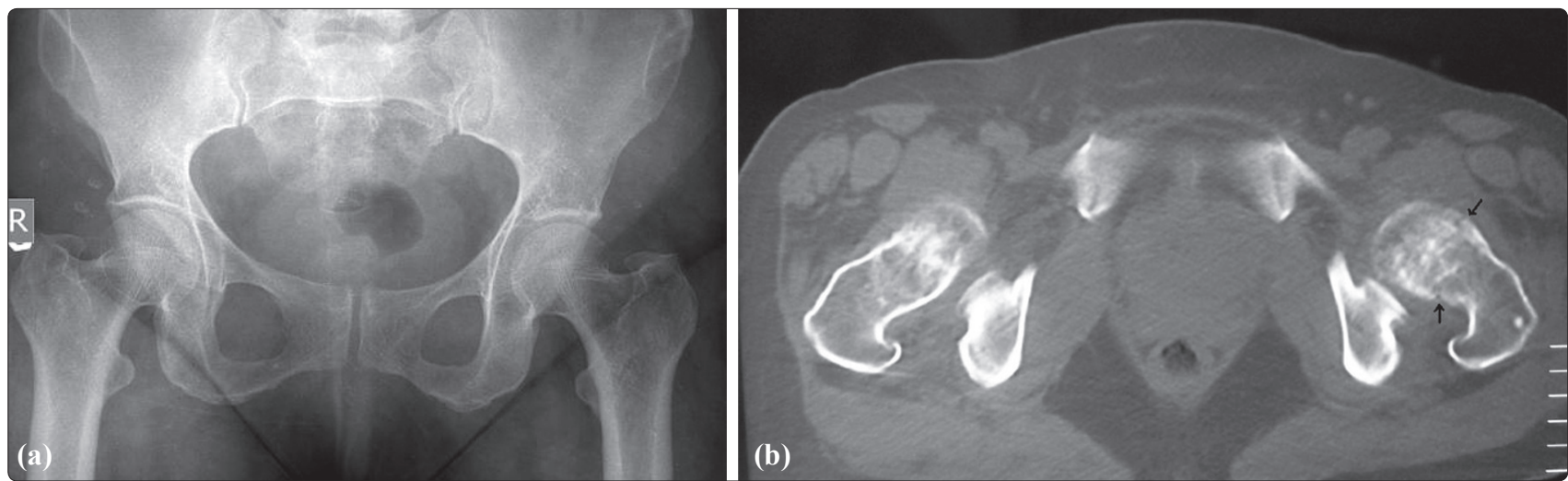

Fig. 2. (a) The normal appearance of the Pelvic AP radiograph. (b) Left collum femoris fracture (black sign) in pelvic CT (black arrow).

knee, the fracture line is separated and causes tendons to stick to the patella, which may need surgical treatment. ${ }^{[7]}$ In our study we found transverse patellar fractures in three patients and vertical patellar fracture in one patient, which healed with conservative treatment.

A large number of patients from almost all age groups were involved in this study. The results are significant when considering patients whose radiographies revealed no fractures after proper anamnesis and regular physical examination in the orthopedical emergencies but who revealed occult factures in the following CTs and were treated starting from the first day. The occult fractures missed in the CT imaging become more complicated to treat, cost more, and the rates of disability increase. Therefore, detecting these occult fractures CTs is a very useful diagnostic tool.

\section{Child}

The term 'occult fracture' is used for a fracture that is either radiographically undetectable or demonstrating subtle abnormalities that were missed on the initial prospective interpretation, even if the fracture is visualized retrospectively or confirmed by other imaging tests. ${ }^{[9,14]}$ Injuries to the physis can occur at any age before physeal closure, but are most common during periods of rapid skeletal growth. Although problems after injury to the physis are uncommon, missed injuries to this area can lead to premature closure with resultant focal bone growth arrest. Fortunately, fractures across the physis usually occur in a predictable pattern. Knowledge of these patterns is key for the emergency physician to avoid this potential orthopedic pitfall. ${ }^{[9,34,35]}$ The incidence of pediatric cases of occult fractures occurs in about $2-18 \%$ of reviewed cases. ${ }^{[3,9]}$ In our study occult fractures were detected using $\mathrm{CT}$ in $12(6.6 \%)$ of the children.

The absence of early management in these children may increase the complication rate. Thus, immobilization is critical for improving healing time, preventing potential growth arrest and fracture deformity, and to avoid discomfort. ${ }^{[3,13]}$ However, the major limitation of this strategy is the undesirable overtreatment, resulting
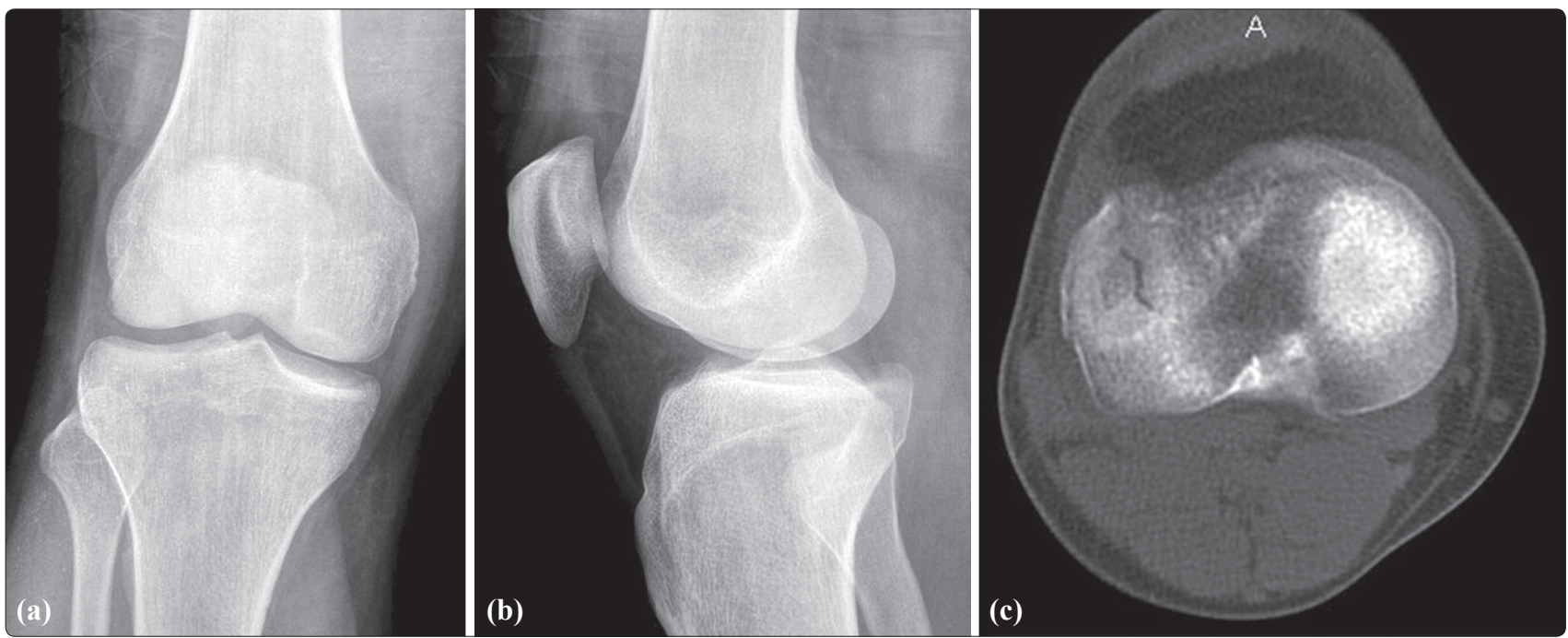

Fig. 3. (a) The normal appearance of the AP knee radiography. (b) The normal appearance of the lateral knee radiography. (c) Occult tibia plateau fracture in knee axial CT. 
in unnecessary limitation of extremity motion, and a 1-2 week follow-up that is imposed on children without a fracture, as well as unnecessary visits for parents or guardians. As a result, about half of the children without fractures can be over treated, and nearly one-third of children with a fracture can be undertreated. ${ }^{[9,13]}$

The limitation of our study is in its retrospective design. The second limitation was our failure to classify fracture types and to evaluate the trauma mechanism because we were concerned about the presence of an occult fracture.

In conclusion, missing the diagnosis of patients with femoral neck fractures, which need immediate surgical treatment, and vertebral fracture, which can cause neurological damage, means destruction for patient and a medicolegal threat for the doctor who relies only on physical examination and direct radiography. As orthopedic surgeons, we should train ourselves about destructive outcomes caused by the risk of missing occult fractures not seen in direct radiography and delay diagnosis, act based on proofed protocols, and request for proper examinations immediately when necessary.

Conflict-of-interest issues regarding the authorship or article: None declared.

\section{REFERENCES}

1. Reisdorf E, Schwartz T. Introduction to emergency radiology. In: Schwartz T, Reisdorf E, editors. Emergency radiology. 1th ed. New York: McGraw-Hill; 2000. p. 1-10.

2. Freed HA, Shields NN. Most frequently overlooked radiographically apparent fractures in a teaching hospital emergency department. Ann Emerg Med 1984;13:900-4.

3. Naranja RJ Jr, Gregg JR, Dormans JP, Drummond DS, Davidson RS, Hahn M. Pediatric fracture without radiographic abnormality. Description and significance. Clin Orthop Relat Res 1997;342:141-6.

4. Germann CA, Perron AD. Risk management and avoiding legal pitfalls in the emergency treatment of high-risk orthopedic injuries. Emerg Med Clin North Am 2010;28:969-96.

5. Vandemark RM. Radiology of the cervical spine in trauma patients: practice pitfalls and recommendations for improving efficiency and communication. AJR Am J Roentgenol 1990;155:465-72.

6. Korres DS, Papagelopoulos PJ, Petrou HG, Tzagarakis GP, Triantafyllidis PG, Tsarouchas J, et al. Occult fracture-dislocation of the cervical spine. Eur J Orthop Surg Traumatol 1999;9:195-9.

7. Capps GW, Hayes CW. Easily missed injuries around the knee. Radiographics 1994;14:1191-210.

8. Lau TW, Leung F. Occult posterior pelvic ring fractures in elderly patients with osteoporotic pubic rami fractures. J Orthop Surg (Hong Kong) 2010;18:153-7.

9. Cho KH, Lee SM, Lee YH, Suh KJ. Ultrasound diagnosis of either an occult or missed fracture of an extremity in pediatric-aged children. Korean J Radiol 2010;11:84-94.

10. Dominguez S, Liu P, Roberts C, Mandell M, Richman PB. Prevalence of traumatic hip and pelvic fractures in patients with suspected hip fracture and negative initial standard ra- diographs--a study of emergency department patients. Acad Emerg Med 2005;12:366-9.

11. Acheson MB, Livingston RR, Richardson ML, Stimac GK. High-resolution CT scanning in the evaluation of cervical spine fractures: comparison with plain film examinations. AJR Am J Roentgenol 1987;148:1179-85.

12. Gangopadhyay S, Akra GA and Nanu AM. Occult hip fractures in the elderly: a protocol for management. Eur J Orthop Traumatol 2007; 17:153-6.

13. Berger PE, Ofstein RA, Jackson DW, Morrison DS, Silvino N, Amador R. MRI demonstration of radiographically occult fractures: what have we been missing? Radiographics 1989;9:407-36.

14. Kan JH, Estrada C, Hasan U, Bracikowski A, Shyr Y, Shakhtour B, et al. Management of occult fractures in the skeletally immature patient: cost analysis of implementing a limited trauma magnetic resonance imaging protocol. Pediatr Emerg Care 2009;25:226-30.

15. Nuñez DB Jr, Zuluaga A, Fuentes-Bernardo DA, Rivas LA, Becerra JL. Cervical spine trauma: how much more do we learn by routinely using helical CT? Radiographics 1996;16:1307-21.

16. Grogan EL, Morris JA Jr, Dittus RS, Moore DE, Poulose BK, Diaz JJ, et al. Cervical spine evaluation in urban trauma centers: lowering institutional costs and complications through helical CT scan. J Am Coll Surg 2005;200:160-5.

17. Freemyer B, Knopp R, Piche J, Wales L, Williams J. Comparison of five-view and three-view cervical spine series in the evaluation of patients with cervical trauma. Ann Emerg Med 1989;18:818-21.

18. MacDonald RL, Schwartz ML, Mirich D, Sharkey PW, Nelson WR. Diagnosis of cervical spine injury in motor vehicle crash victims: how many X-rays are enough? J Trauma 1990;30:392-7.

19. Berlin L. CT versus radiography for initial evaluation of cervical spine trauma: what is the standard of care? AJR Am J Roentgenol 2003;180:911-5.

20. el-Khoury GY, Kathol MH, Daniel WW. Imaging of acute injuries of the cervical spine: value of plain radiography, CT, and MR imaging. AJR Am J Roentgenol 1995;164:43-50.

21. France JC, Bono CM, Vaccaro AR. Initial radiographic evaluation of the spine after trauma: when, what, where, and how to image the acutely traumatized spine. J Orthop Trauma 2005; 19:640-9.

22. Diaz JJ Jr, Gillman C, Morris JA Jr, May AK, Carrillo YM, Guy J. Are five-view plain films of the cervical spine unreliable? A prospective evaluation in blunt trauma patients with altered mental status. J Trauma 2003;55:658-64.

23. Bachulis BL, Long WB, Hynes GD, Johnson MC. Clinical indications for cervical spine radiographs in the traumatized patient. Am J Surg 1987; 153:473-8.

24. Blacksin MF, Lee HJ. Frequency and significance of fractures of the upper cervical spine detected by $\mathrm{CT}$ in patients with severe neck trauma. AJR Am J Roentgenol 1995;165:1201-4.

25. Jelly LM, Evans DR, Easty MJ, Coats TJ, Chan O. Radiography versus spiral CT in the evaluation of cervicothoracic junction injuries in polytrauma patients who have undergone intubation. Radiographics 2000;20:251-62.

26. Bagley LJ. Imaging of spinal trauma. Radiol Clin North Am 2006;44:1-12.

27. Poonnoose PM, Ravichandran G, McClelland MR. Missed and mismanaged injuries of the spinal cord. J Trauma 2002;53:314-20. 
28. Reid DC, Henderson R, Saboe L, Miller JD. Etiology and clinical course of missed spine fractures. J Trauma 1987;27:980-6.

29. Hauser CJ, Visvikis G, Hinrichs C, Eber CD, Cho K, Lavery $\mathrm{RF}$, et al. Prospective validation of computed tomographic screening of the thoracolumbar spine in trauma. J Trauma 2003;55:228-35.

30. White JH, Hague C, Nicolaou S, Gee R, Marchinkow LO, Munk PL. Imaging of sacral fractures. Clin Radiol 2003;58:914-21.

31.Perron AD, Brady WJ, Keats TE, Hersh RE. Orthopedic pitfalls in the ED: scaphoid fracture. Am J Emerg Med
2001;19:310-6.

32. Breitenseher MJ, Gaebler C. Trauma of the wrist. Eur J Radiol 1997;25:129-39.

33. Perron AD, Miller MD, Brady WJ. Orthopedic pitfalls in the ED: radiographically occult hip fracture. Am J Emerg Med 2002;20:234-7.

34. Perron AD, Miller MD, Brady WJ. Orthopedic pitfalls in the ED: pediatric growth plate injuries. Am J Emerg Med 2002;20:50-4.

35. Della-Giustina K, Della-Giustina DA. Emergency department evaluation and treatment of pediatric orthopedic injuries. Emerg Med Clin North Am 1999;17:895-922. 